\title{
Impacts of trade liberalisation on aggregate import in Bangladesh: an ARDL bounds test approach
}

\begin{abstract}
Bangladesh has been liberalising its trade regime extensively since 1992 in order to achieve higher trade performance and GDP growth. However, despite the long period of liberalisation, imports are still growing faster than exports, increasing the trade deficit. Trade liberalisation is considered a crucial contributory factor. The paper examines the impact of trade liberalisation on the aggregate import in Bangladesh, using the ARDL Bounds Test approach with annual time series data from 1972ï 1973 to 2004ï 2005. Empirical results suggest that trade liberalisation through reduction of the import duty rate increases the aggregate import substantially in the short run, but insignificantly in the long run. Trade liberalisation using simplification of non-tariff measures shows a significant but low positive impact on the aggregate import in the long run. Liberalisation interaction with price decreases imports slightly hence improves the trade balance, while interaction with income increases imports slightly hence worsens the trade balance. An increase in imports is mainly stimulated by an increase in income. Moreover, higher income elasticity compared to price elasticity indicates that an effort to maintain imports at the desired level by increasing import duty could be counter balanced and ineffective. Therefore, a consistent policy to promote not only consumption of domestically produced products, but investment, production, and backward linkage industries is essential in order to improve the trade balance and GDP growth in Bangladesh.
\end{abstract}

Keyword: Trade liberalisation; Aggregate import; ARDL 'bounds test'; Short run and long run impacts; Interaction impacts 